\title{
KEKUATAN HUKUM MEMORANDUM OF UNDERSTANDING (MoU) DALAM HUKUM PERJANJIAN DI INDONESIA
}

\author{
Gita Nanda Pratama \\ email: gitanandap@gmail.com
}

\begin{abstract}
Memorandum of Understanding (MoU), made orally or in written form, is used as the basis for drafting a contract containing elaboration of the parties' specific rights and duties. MoU may thus be understood as a preliminary agreement to draft a contract. The author, starting from the Indonesian contract law, intend to analyze the extent to which MoU may be considered legally binding by the parties. To that purpose a comparison with how common law system recognize and regulate MoU will be considered necessary. The author's main argument is that, notwithstanding the fact that there is no rule explicitly recognizing or mentioning the name, MoU's containing the main understandings reached by parties should be treated as morally binding by the parties.
\end{abstract}

Keywords:

Memorandum of Understanding (MoU), contract-agreements.

\begin{abstract}
Abstrak
Memorandum of Understanding (MoU) atau dalam bahasa Indonesia disebut Nota Kesepahaman adalah dasar penyusunan kontrak yang didasarkan pada hasil permufakatan para pihak baik, yang dituangkan dalam bentuk tertulis maupun lisan. Hasil permufakatan ini mendahului pembuatan perjanjian yang lebih terperinci yang memuat hak dan kewajiban para pihak. Penulis di sini hendak menganalisis kedudukan dan kekuatan mengikat memorandum of understanding (MoU) berdasarkan hukum perjanjian di Indonesia serta membandingkannya dengan keberlakuan MoU dalam sistem hukum common law. Kesimpulan yang dapat ditarik ialah bahwa MoU sebagai nota kepahaman memuat kesepakatan dalam pokok-pokoknya saja dan dalam sistem hukum perikatan Indonesia tetap harus dipandang mengikat setidaknya pada tataran moral.
\end{abstract}

Kata Kunci:

Memorandum of Understanding (MoU), kontrak-perjanjian.

\section{Pengantar}

Negara Indonesia adalah negara hukum yaitu negara yang berlandaskan pada peraturan perundang-undangan yang telah ditetapkan oleh pemerintah dan dijadikan pedoman dalam kehidupan bermasyarakat. Peraturan-peraturan tersebut bertujuan tercapainya masyarakat Indonesia yang baik, tentram dan damai.

Hukum perjanjian merupakan bagian dari hukum di Negara Indonesia yang berkaitan dengan kesepakatan antara pihak satu dengan pihak lainnya. Perjanjian dapat dilakukan oleh berbagai pihak, baik para pihak di dalam negara maupun antar Negara. Di era globalisasi ini, dengan perkembangan bisnis yang sangat pesat, negara-negara (khususnya ASEAN) melakukan perjanjian dengan tujuan 
memajukan derajat masyarakat Indonesia yang baik dengan mengacu kepada itikad baik (Good Faith). Namun hal tersebut dalam prakteknya, tidak selalu seiring dengan hukum dan ketentuan-ketentuan yang berlaku, dikarenakan tingkat kesadaran hukum yang dimiliki oleh khususnya masyarakat Indonesia masih lemah. Sifat masyarakat Indonesia yang terkadang tidak mentaati peraturan atau normanorma kaidah yang berlaku, bertolak belakang dengan ketentuan yang berlaku mengenai perjanjian antara para pihak, di mana para pihak hanya dapat menutup perjanjian dengan menyepakati akibat-akibat hukum yang berasal dari pokokpokok perjanjian saja. Karena suatu perjanjian biasanya hanya menentukan ketentuan-ketentuan pokoknya saja. Karena hal-hal itulah permasalahan hukum yang aktual atas perjanjian biasanya terjadi.

Hal yang penting dalam perjanjian adalah bahwa sebuah perjanjian terkait dengan tindakan-tindakan hukum. Karena melalui tindakan-tindakan hukum, manusia dapat menyelenggarakan kepentingan dan kewajiban-kewajibannya. Bahwa dalam perjanjian pada dasarnya kepentingan yang terikat oleh apa yang dituliskan dalam perjanjian yang bersangkutan adalah kepentingan para pihak sendiri, yang telah dengan suka-rela dan persetujuannya sengaja dilibatkan. ${ }^{1}$

Dalam hal ini, suatu kontrak atau perjanjian bermula dari perbedaan kepentingan antara pihak satu dengan pihak lain, sehingga perumusan hubungan kontraktual dimulai dengan proses negosiasi para pihak. Setelah terbentuknya kesepahaman atas kehendak para pihak masing-masing, para pihak akan membentuk suatu proses prakontraktual sebagai nota kesepahaman atau sering disebut dengan istilah "Memorandum of Understanding" (MoU). Setelah terbentuknya nota kesepahaman yang telah disepakati oleh para pihak, maka terwujudnya sebuah kesepakatan untuk adanya kontrak yang pasti. Kontrak tersebut dinamakan sebagai perjanjian yang mengacu kepada Pasal 1320 Kitab Undang-Undang Hukum Perdata tentang syarat umum sahnya suatu perjanjian di Indonesia. Namun Pasal 1320 KUH Perdata tersebut tidak mengatur mengenai hal

1 J. Satrio, Hukum Perjanjian, PT. Citra Aditya Bakti, Bandung, 1992, hlm. 14. 
MoU (Memorandum of Understanding). Karenanya diperlukan penafsiran untuk membahas tentang kekuatan MoU menurut hukum yang berlaku.

Hal menjadi perdebatan hingga saat ini adalah mengenai kekuatan hukum yang mengikat dari MoU (Memorandum of Understanding) sebagai perihal awal terbentuknya perjanjian. Mengingat bahwa negara Indonesia menganut sistem hukum Eropa Kontinental, yang menggunakan pola-pola dogmatis, di mana dalam sebuah transaksi dapat segera dibuat perumusan kehendak para pihak dalam sebuah perjanjian. ${ }^{2}$ Dalam sistem civil law, suatu hal yang tidak diatur dalam perjanjian, akan mengacu pada ketentuan perundang-undangan yang lebih tinggi.

Berbeda halnya dengan sistem common law, di mana dalam sebuah perjanjian harus telah diatur secara terperinci segala sesuatu termasuk segala kemungkinan yang akan terjadi akibat dari ditandatanganinya sebuah perjanjian. ${ }^{3}$ Dengan kata lain, perlunya komitmen atau kesepakatan bersama dari para pihak yang terkait untuk mengatur kehendak atau kesepahaman pemikiran yang sejalan dengan tujuan perjanjian antara para pihak.

Melihat penjelasan di atas, dapat disimpulkan karena negara Indonesia menganut sistem hukum dari civil law, di mana setiap anggota masyarakat akan mengacu terhadap ketentuan undang-undang yang lebih tinggi, maka kedudukan MoU (Memorandum of Understanding) harus mendapat perhatian karena tidak adanya pengaturan secara eksplisit di dalam pasal 1320 KUH Perdata.

Secara sederhana konsep dari Memorandum of Understanding (MoU) adalah suatu nota kesepakatan yang dilakukan oleh para pihak yang ingin melakukan perjanjian. Akan tetapi, bila Memorandum of Understanding (Mou) tersebut juga mengacu kepada Pasal 1320 KUH Perdata, maka ia memiliki kekuatan hukum yang sama dengan kekuatan hukum berdasarkan perjanjian yang terdapat di dalam sistem hukum Negara Indonesia, yakni sistem hukum Civil Law.

\footnotetext{
2 Pemikiran dan Referensi Hukum, http://arididit.blogspot.com/2014/10/ (terakhir diakses 7 Desember 2015)

3 Id.
} 


\section{MoU (Memorandum of Understanding)}

Istilah MoU (Memorandum of Understanding) pasti sudah tidak asing lagi di dalam ruang lingkup hukum khususnya di wilayah perjanjian. Seiring berjalan MoU seringkali menjadi dasar awal terbentuknya perjanjian bagi kerjasama antara para pihak. Istilah memorandum of understanding berasal dari dua kata, yaitu memorandum dan understanding.

Dalam Black's Law Dictionary, yang dimaksud memorandum adalah "dasar untuk memulai penyusunan kontrak secara formal pada masa datang (is to serve as the basis of future formal contract)."4

Sedangkan yang dimaksud dengan understanding adalah "pernyataan persetujuan secara tidak langsung terhadap hubungannya dengan persetujuan lain, baik secara lisan maupun secara tertulis (an implied agreement resulting from the express term of another agreement, whether written or oral)." 5

Dari pengertian di atas dapat disimpulkan bahwa memorandum of understanding adalah dasar penyusunan kontrak pada masa datang yang didasarkan pada hasil permufakatan para pihak, baik secara tertulis maupun lisan. MOU dapat diartikan pula sebagai perjanjian pendahuluan, yang mengatur dan memberikan kesempatan kepada para pihak untuk melakukan studi kelayakan terlebih dahulu sebelum membuat suatu perjanjian yang lebih terperinci dan mengikat para pihak nantinya yang akan tertuang dalam kontrak.

Selanjutnya menurut para ahli tentang Memorandum of Understanding (MoU), adalah sebagai berikut: Munir Fuady, mengartikan memorandum of understanding sebagai "Perjanjian pendahuluan, dalam arti nantinya akan diikuti dan dijabarkan dalam perjanjian lain yang mengaturnya secara detail, karena itu, memorandum of understanding berisikan hal-hal yang pokok saja. Adapun mengenai lain-lain aspek dari memorandum of understanding relatif sama dengan perjanjian-

\footnotetext{
4 H. Salim HS, H. Abdullah, Wiwiek Wahyuningsih, Perancangan Kontrak \&Memorandum of Understanding (MoU), Sinar Grafika, Jakarta, 2014, hlm. 46.

5 Id.
} 
perjanjian lain."6 Sedangkan menurut Erman Rajagukguk memorandum of understanding adalah "Dokumen yang memuat saling pengertian di antara para pihak sebelum perjanjian dibuat. Inti dari memorandum of understanding harus dimasukkan ke dalam kontrak, sehingga ia mempunyai kekuatan mengikat."7 I. Nyoman Sudana, dkk mengartikan memorandum of understanding sebagai suatu perjanjian pendahuluan, dalam arti akan diikuti perjanjian lannya. ${ }^{8}$

Dari ketiga definisi tersebut didapat unsur-unsur dari MOU sebagai berikut:

1) Memorandum of Understanding adalah perjanjian pendahuluan;

2) Isi memorandum of understanding adalah mengenai hal-hal yang pokok; dan

3) Isi memorandum of understanding akan dimasukkan dalam kontrak. ${ }^{9}$

Hingga saat ini pengaturan yang mewajibkan secara khusus mengenai MoU (Memorandum of Understanding) yang dituangkan secara sah ke dalam UndangUndang belum tersedia. Hanya saja, merujuk dari penjelasan di atas, di mana MoU dapat dikatakan sebagai perjanjian pendahuluan, maka pengaturannya tetap tunduk pada ketentuan pasal 1320 dalam Buku III Kitab Undang-Undang Hukum Perdata.

Di dalam pasal 1320 KUHPerdata diatur tentang syarat-syarat sahnya perjanjian. Salah satu syarat sahnya perjanjian itu adalah bagaimana kesepakatan antar pihak satu dengan pihak yang lain. Tetapi di dalam Buku III Kitab UndangUndang Hukum Perdata ada pasal yang dapat menguatkan dan menjadikan dasar hukum dari terbentuknya Memorandum of Understanding (MoU) yakni pasal 1338 KUH Perdata, yang berbunyi:

"Semua perjanjian yang dibuat secara sah berlaku sebagai undangundang bagi mereka yang membuatnya."10

Seperti diketahui Memorandum of Understanding (MoU) berasal dari Common Law System. Sedangkan Negara Indonesia memiliki sistem hukum Eropa

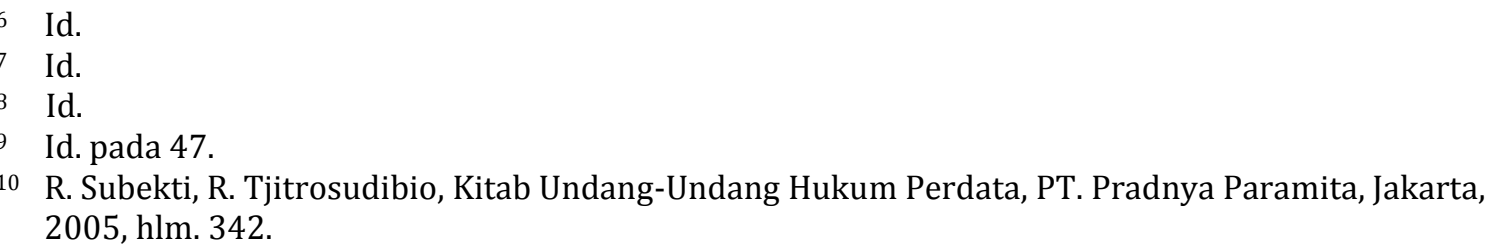


Kontinental/Civil Law System. Walaupun MoU berasal dari Common Law System, tetapi pada praktiknya MoU dapat dilakukan di negara-negara yang menganut Civil Law System yang salah satunya dianut oleh Negara Indonesia.

Munir Fuady mengemukakan ciri-ciri memorandum of understanding sebagai berikut:

1) Isinya ringkas, bahkan sering sekali satu halaman saja;

2) berisikan hal yang pokok saja;

3) bersifat pendahuluan saja, yang akan diikuti oleh perjanjian lain yang lebih rinci;

4) mempunyai jangka waktunya, misalnya satu bulan, enam bulan, atau setahun. Apabila dalam jangka waktu tersebut tidak ditindaklanjuti dengan suatu perjanjian yang lebih rinci, perjanjian tersebut akan batal, kecuali diperpanjang oleh para pihak;

5) biasanya dibuat dalam bentuk perjanjian di bawah tangan; dan

6) biasanya tidak ada kewajiban yang bersifat memaksa kepada para pihak untuk membuat suatu perjanjian yang lebih detail setelah penandatanganan memorandum of understanding, karena secara reasonable barangkali kedua belah pihak punya rintangan untuk membuat dan menandatangani perjanjian yang detail tersebut. ${ }^{11}$

Adapun tujuan dibuatnya Memorandum of Understanding yang dibuat oleh para pihak, tentunya mempunyai tujuan tertentu. Munir Fuady telah mengemukakan tujuan Memorandum of Understanding yaitu: ${ }^{12}$

1) Untuk menghindari kesulitan pembatalan suatu agreement nantinya, dalam hal prospek bisnisnya belum jelas benar, dalam arti belum bisa dipastikan apakah kesepakatan kerja sama tersebut akan ditindaklanjuti, sehingga dibuatlah memorandum of understanding yang mudah dibatalkan;

\footnotetext{
11 Munir Fuady, Memoradum of Understanding, hlm. 91-92.

12 Id.
} 
2) Penandatanganan kontrak masih lama karena masih dilakukan negosiasi yang alot. Karena itu daripada tidak ada ikatan apa-apa sebelum ditandatangani kontrak tersebut, dibuatlah memorandum of understanding yang akan berlaku sementara waktu;

3) Adanya keraguan para pihak dan masih perlu waktu untuk pikir-pikir dalam hal penandatanganan suatu kontrak, sehingga untuk sementara dibuatlah memorandum of understanding.

4) Memorandum of understanding dibuat dan ditandatangani oleh pihak eksekutif dari suatu perusahaan, sehingga untuk suatu perjanjian yang lebih rinci mesti dirancang dan dinegosiasi khusus oleh staf-staf yang lebih rendah tetapi lebih menguasai secara teknis

Memorandum of Understanding (MoU) merupakan suatu nota di mana para pihak melakukan penandatanganan MoU sebagai suatu pedoman awal mula suatu kesepahaman antara para pihak yang merujuk kepada suatu perjanjian dan MoU tidak memiliki ikatan yang kuat diantara para pihak. Akan tetapi apabila MoU di dalamnya memenuhi unsur-unsur yang terkait dalam Pasal 1320 KUHPerdata, hal ini merupakan suatu perjanjian yang memiliki kekuatan hukum yang mengikat seperti perjanjian sehingga seluruh ketentuan yang tercantum dapat diterapkan kepada para pihak. Dengan demikian, apabila salah satu dari para pihak tidak melaksanakan atau tidak melakukan sesuai ketentuan MoU yang telah dibuat, maka salah satu pihak dapat membawa persoalan tersebut ke dalam pengadilan dan pihak yang berwenang dapat memerintahkan salah satu pihak untuk dapat melaksanakan substansi memorandum of understanding secara konsisten.

Hal selanjutnya, setelah mengetahui pengertian dari Memorandum of Understanding (MoU) serta adanya kekuatan hukum yang mendukung, tujuan dan unsur-unsur yang terdapat di dalamnya, penulis akan membahas tentang pengertian dari perjanjian yang terkandung dalam Buku III Kitab Undang-Undang Hukum Perdata dan Hukum Kontrak. 


\section{Perjanjian dan Hukum Kontrak}

Kata "perjanjian" dapat mempunyai arti yang luas dan sempit. "Dalam arti luas suatu perjanjian berarti setiap perjanjian yang menimbulkan akibat hukum sebagai yang dikehendaki (atau dianggap dikehendaki) oleh para pihak, termasuk di dalamnya perkawinan, perjanjian kawin dan lain-lain."13 "Dalam arti sempit "perjanjian" di sini hanya ditujukan kepada hubungan-hubungan hukum dalam lapangan hukum kekayaan saja, seperti yang dimaksud oleh Buku III B.W."14

Dalam Buku III Kitab Undang-Undang Hukum Perdata Pasal 1313 mendefinisikan arti perjanjian sebagai "Suatu perjanjian adalah suatu perbuatan dengan mana satu orang atau lebih mengikatkan dirinya terhadap satu orang lain atau lebih."15

Selanjutnya, Buku III Kitab Undang-Undang Hukum Perdata di mana di dalam buku tersebut dijelaskan mengenai pengertian dari syarat sahnya perjanjian. Pasal 1320 KUH Perdata mengatakan bahwa syarat sahnya perjanjian diperlukan empat syarat:

1) Sepakat mereka yang mengikatkan dirinya;

2) Kecakapan untuk membuat suatu perjanjian;

3) Suatu hal tertentu; dan

4) Suatu sebab yang halal. ${ }^{16}$

Jadi, pada dasarnya suatu perjanjian adalah suatu tindakan hukum yang mengikat antar para pihak yang bersangkutan yang tertuang dalam kontrak disertai kata kesepatakan. Namun di dalam prakteknya, seringkali orang yang menutup suatu perjanjian hanya mengetahui akibat-akibat hukum yang berasal dari pokokpokoknya saja, karena di dalam perjanjian hanya dimuat ketentuan-ketentuan yang pokok saja tanpa memberikan ketentuan secara terperinci.

13 J. Satrio, supra no. 2, hlm. 23.

14 Id.

15 R. Subekti, R. Tjitrosudibio, supra no. 10, hlm. 338.

16 Id. HIm. 339. 
Pembicaraan tentang perjanjian dalam kaitannya dengan tindakan hukum merupakan pokok pembicaraan yang penting, karena melalui tindakan-tindakan hukum, manusia menyelenggarakan kepentingan-kepentingannya, sedang di antara tindakan-tindakan hukum manusia, tindakan menutup perjanjian memegang peranan yang paling utama. Melalui perjanjian orang mendapatkan, mengubah dan melepaskan hak-hak serta kewajiban-kewajibannya. Hampir tidak ada hak dan kewajiban yang tidak didapatkan dan diperoleh dari orang melalui perjanjian.

Adapun Subyek dan Obyek dalam Perjanjian, di antaranya:

\section{Subyek}

1) Seorang manusia atau suatu badan hukum yang mendapat beban kewajiban untuk sesuatu; dan

2) Seorang manusia atau suatu badan hukum yang mendapat hak atas pelaksanaan kewajiban itu. ${ }^{17}$

\section{Obyek}

1) Hal yang diwajibkan kepada pihak-berwajib (debitur); dan

2) Hal terhadap mana pihak-berhak (kreditur) mempunyai hak. ${ }^{18}$

\section{Asas-Asas yang terkandung dalam Perjanjian}

\section{Asas Kebebasan Berkontrak (Freedom of Contract)}

Asas kebebasan berkontrak dapat dianalisis dari ketentuan Pasal 1338 ayat (1) KUH Perdata, yang berbunyi "Semua perjanjian yang dibuat secara sah berlaku sebagai Undang-Undang bagi mereka yang membuatnya." Prinsip kebebasan untuk berkontrak (freedom of contract) sebagaimana tercantum dalam Pasal 1338 KUH Perdata itu mencakup:

1) Kebebasan untuk menentukan kehendak menyetujui atau tidak menyetujui dibuatnya suatu perjanjian;

2) Kebebasan untuk memilih dengan pihak mana akan dibuat suatu perjanjian;

17 R. Wirjono Prodjodikoro, Azas-Azas Hukum Perjanjian, CV. Mandar Maju, Bandung, 2000, hlm. 13.

18 Id. hlm., 19. 
3) Kebebasan untuk menetapkan isi perjanjian;

4) Kebebasan untuk menetapkan bentuk perjanjian;

5) Kebebasan untuk menetapkan cara pembuatan perjanjian. ${ }^{19}$

Latar belakang lahirnya asas kebebasan berkontrak adalah adanya paham individualisme yang secara embrional lahir dalam zaman Yunani, yang diteruskan oleh kaum Epicuristen dan berkembang pesat dalam zaman renaisans melalui antara lain ajaran-ajaran Hugo de-Grecht, Thomas Hobbes, Jhon Locke, dan Rosseau. Menurut paham individualisme, setiap orang bebas untuk memperoleh apa yang dikehendakinya. dalam hukum kontrak asas ini diwujudkan dalam "kebebasan berkontrak". Paham Individualisme memberikan peluang yang luas kepada golongan ekonomi kuat untuk menguasai golongan ekonomi lemah. ${ }^{20}$

\section{Asas Konsensualisme (concensualism)}

Lebih jauh, asas konsensualisme (kesepakatan, consensus) sebagaimana tercantum dalam Pasal 1320 KUH Perdata menekankan kesepakatan di antara para pihak yang membuat perjanjian, yang ditandai dengan apa yang dikehendaki oleh pihak yang satu sebagai juga dikehendaki oleh pihak lainnya secara seketika. Suatu konsensus dianggap tidak ada, atau jika ada, bisa dinyatakan cacat, bila terdapat salah satu dari tiga halangan yang ditentukan dalam Pasal 1321 KUH Perdata, yaitu:

1) Kekhilafan (Ned: dwaling, Eng: oversight);

2) Paksaan (Ned: dwang, Eng: coercion);

3) Penipuan (Ned: bedrog, Eng: fraud). ${ }^{21}$

Asas konsensualisme dapat disimpulkan dalam Pasal 1320 ayat (1) KUH Perdata. Pada pasal tersebut ditentukan bahwa salah satu syarat sahnya perjanjian adalah kata kesepakatan antara kedua belah pihak. Asas ini merupakan asas yang menyatakan bahwa perjanjian pada umumnya tidak diadakan secara formal, melainkan cukup dengan adanya kesepakatan kedua belah pihak. Kesepakatan

19 Budiono Kusumohamidjojo, Perbandingan Hukum Kontrak, Mandar Maju, Bandung, 2015, hlm. 61.

20 Supra no. 5, hlm 2.

21 Id. hlm. 63. 
adalah persesuaian antara kehendak dan pernyataan yang dibuat oleh kedua belah pihak.

\section{Asas Kepastian Hukum (Pacta sunt servanda)}

Asas kepastian hukum atau disebut juga dengan asas pacta sunt servanda merupakan asas yang berhubungan dengan akibat perjanjian. Asas ini menyatakan bahwa hakim atau pihak ketiga harus menghomati substansi kontrak yang dibuat oleh para pihak, sebagaimana layaknya sebuah undang-undang. Mereka tidak boleh melakukan intervensi terhadap sebuah undang-undang.

Hal selanjutnya, setelah mengetahui pengertian dari perjanjian yang tercantum dalam Buku III Kitab Undang-Undang Hukum Perdata serta adanya kekuatan hukum yang mendukung, tujuan dan unsur-unsur yang terdapat di dalamnya maka penulis akan meneruskan pembahasan tentang pengertian Hukum Kontrak.

Seperti dalam pembahasan sebelumnya, perjanjian memiliki kaitan dengan unsur-unsur yang terdapat di dalam kontrak. Bahwa suatu kontrak merupakan suatu kesepakatan yang dapat dilaksanakan oleh pengadilan berdasarkan hukum yang berlaku, kepatutan dan kelayakan. Yang dimaksud dengan kontrak adalah suatu janji atau seperangkat janji-janji dan akibat pengingkaran atau pelanggaran atasnya hukum memberikan pemulihan atau menetapkan kewajiban bagi yang ingkar janji disertai sanksi untuk pelaksanaannya. ${ }^{22}$

Setiap kontrak yang dibuat harus melibatkan sekurang-kurangnya dua pihak atau lebih. Karena di dalamnya terdapat pihak yang menawarkan bisa juga disebut sebagai offeror yakni pihak yang mengajukan penawaran untuk membuat suatu kontrak, disamping itu ada juga pihak yang ditawari dari sebuah kontrak biasa disebut sebagai offeree yakni pihak di mana kontrak tersebut ditawarkan.

Terdapat unsur-unsur yang mendukung demi terwujudnya suatu kontrak yang dapat dilaksanakan, yaitu:

22 Soedjono Dirdjosisworo, Kontrak Bisnis, CV. Mandar Maju, Bandung, 2003, hlm. 29. 
1. Kesepakatan: Untuk memperoleh suatu kontrak yang bisa dilaksanakan, para pihak harus telah saling menerima kesepakatan. Kesepakatan ini antara pihak offeror dan offeree;

2. Pertimbangan: Janji tersebut harus didukung tawar-menawar yang dijadikan pertimbangan berdasarkan ketentuan perundang-undangan. Seringkali janji-janji untuk memberi dan kewajiban-kewajiban moral tidak didukung oleh pertimbangan yang sah.

3. Kapasitas mengadakan kontrak: pihak-pihak dalam kontrak harus memiliki kapasitas atau kemampuan untuk mengadakan kontrak.

4. Obyek yang sah: Obyek kontrak haruslah sah atau tidak melawan hukum. Kontrak diadakan untuk mencapai tujuan-tujuan atau obyek illegal atau kontrak-kontrak yang berlawanan atau bertentangan dengan kebijkaksanaan pemerintah menjadi batal. ${ }^{23}$

Dari penjelasan-penjelasan mengenai Memorandum of Understanding (MoU) di atas mengenai kaitan ketentuan dasar yang menjadi dasar hukum adanya MoU berdasarkan Buku III Burgerlijk Wetboek (K.U.H.Perdata) Pasal 1338 ayat 1 adalah semua perjanjian yang dibuat secara sah akan berlaku sebagai undang-undang bagi mereka yang membuatnya. Apabila telah terjadi persesuaian pernyataan kehendak dan telah ditandatangani kerja sama oleh para pihak, maka memorandum of understanding (MoU) telah mempunyai kekuatan hukum untuk dapat dilaksanakan dan mempunyai kekuatan mengikat antara para pihak. Mengingat bahwa dengan dibuatnya suatu MoU dengan menggunakan itikad baik (Good Faith) yang telah disepakati para pihak menunjukan bahwa MoU memiliki kekuatan hukum yang mengikat.

Memorandum of Understanding (MoU) juga dapat terbentuk atas dasar kerja sama yang dilakukan oleh negara satu dengan negara yang lain. Mengingat bahwa sistem negara Indonesia yakni berdasarkan sistem hukum civil law, maka dari itu pengaturan secara konkrit mengenai kedudukan hukum Memorandum of

23 Id. pada 30,31 . 
Understanding (MoU) di Indonesia tidak diberlakukan secara tegas. Mengingat Memorandum of Understanding (MoU) berdasarkan sistem hukum common law itu hanya sebatas nota kesepahaman, bukan berarti MOU memiliki dasar hukum yang kuat sebagai syarat sahnya dalam suatu perjanjian.

Negara Indonesia yang memiliki sekumpulan peraturan-peraturan mengenai kontrak perjanjian yang ditegaskan dalam Buku III Kitab Undang-Undang Hukum Perdata Pasal 1320 mengenai syarat sahnya perjanjian. Menurut pasal tersebut apabila para pihak ingin melakukan sebuah perjanjian, maka dasar hukum yang menguatkan dan menjadi pedoman merujuk kepada pasal tersebut.

Di dalam Buku III Kitab Undang-Undang Hukum Perdata Pasal 1338 ditegaskan bahwa perjanjian yang dibuat dengan dasar itikad baik dan tidak bertentangan dengan undang-undang berlaku sebagai undang-undang bagi mereka yang membuatnya. Demikian halnya dengan Memorandum of Understanding itu dibuat memenuhi unsur-unsur dari suatu perjanjian. Maka dari itu, Pasal $1338 \mathrm{KUH}$ Perdata dijadikan salah satu dasar hukum Memorandum of Understanding. Pasal tersebut melahirkan hak dan kewajiban yang akhirnya memiliki sanksi moral antar para pihak.

Adanya asas kebebasan berkontrak, adalah suatu asas yang memberikan kebebasan kepada para pihak untuk:

(1) membuat atau tidak membuat perjanjian;

(2) mengadakan perjanjian dengan siapapun;

(3) menentukan isi perjanjian, pelaksanaan dan persyaratannya; dan

(4) menentukan bentuk perjanjian yaitu tertulis atau lisan. ${ }^{24}$

Adanya asas kebebasan berkontrak sangat penting karena ketentuanketentuan di dalamnya.Apabila salah satu pihak melakukan pelanggaran terhadap Memorandum of Understanding dan dinyatakan telah terbukti merupakan perbuatan yang melawan hukum, maka pihak tersebut dapat dituntut untuk mengganti kerugian yang telah ditimbulkannya. Ganti rugi yang dimaksud adalah

24 Supra no 2, hlm. 48. 
biaya yang telah dikeluarkan, kerugian yang diderita dan keuntungan yang mungkin akan diperoleh. Sanksi yang diperoleh adalah sanksi sebatas moral saja, karena Memorandum of Understanding tidak memiliki sanksi yang bersifat memaksa.

\section{Wanprestasi}

Wanprestasi, artinya tidak memenuhi kewajiban sebagaimana ditetapkan dalam perikatan atau perjanjian. Tidak dipenuhinya kewajiban dalam suatu perjanjian, dapat disebabkan oleh dua hal, yaitu:

(1) Karena kesalahan debitur baik sengaja maupun kelalaian; dan

(2) Karena keadaan memaksa (Overmacht/Forcemajeur) ${ }^{25}$

Djaja S. Meliala, bahwa ada empat unsur keadaan wanprestasi, yakni di antaranya:

(1) Tidak memenuhi prestasi;

(2) Terlambat memenuhi prestasi;

(3) Memenuhi prestasi secara tidak baik; dan

(4) Melakukan sesuatu yang menurut perjanjian tidak boleh dilakukannya. ${ }^{26}$

Seorang dapat dikatakan melakukan pelanggaran terhadap prestasi yang telah disepakati oleh para pihak di dalam suatu kontrak yaitu bila tidak melakukan hak dan kewajiban dengan baik sesuai prestasinya, yang dinamakan wanprestasi. Dari penjelasan di atas, dapat disimpulkan bahwa pihak yang tidak melakukan prestasi akan dikenakan sanksi.

Adanya gugatan terhadap wanprestasi atas lalainya salah satu pihak dalam perjanjian yang berbentuk Memorandum of Understanding ditujukan kepada pihak yang tidak melakukan prestasinya atas kewajiban hukum sesuai perjanjian sehingga ada pihak yang merasa dirugikan dan menimbulkan akibat hukum. Pengingkaran perjanjian oleh salah satu pihak dalam MOU dapat berakibat pada tuntutan berupa:

\footnotetext{
25 Djaja S. Meliala, Perkembangan Hukum Perdata Tentang Benda Dan Hukum Perikatan, Nuansa Aulia, Bandung, 2007, hlm. 99.

26 Id. hlm. 99-100.
} 
(1) pemenuhan isi kesepakatan dalam Memorandum of Understanding;

(2) pemenuhan isi kesepakatan dalam Memorandum of Understanding ditambah dengan ganti rugi;

(3) ganti rugi;

(4) pembatalan Memorandum of Understanding; dan

(5) pembatalan Memorandum of Understanding ditambah dengan ganti rugi.

Karena pendapat tentang kedudukan Memorandum of Understanding yang berbeda-beda, Munir Fuady juga mengemukakan dua pandangan yang membahas tentang kekuatan mengikat dari Memorandum of Understanding, yaitu:

1) Gentlement agreement

Kekuatan mengikat suatu memorandum of understanding tidak sama dengan perjanjian biasa, sekalipun memorandum of understanding dibuat dengan bentuk yang paling kuat, seperti dengan akta notaris. Hal tersebut hanya sebatas pengikatan moral belaka, apabila digugat secara wanprestasi, sanksinya hanya berupa ikatan moral saja dan tidak sampai ke pengadilan karena tidak memiliki daya ikat secara hukum.

2) Agreement is agreement

Dalam suatu perjanjian yang dibuat, apa pun bentuknya, lisan atau tertulis tetap saja merupakan perjanjian dan karenanya mempunyai kekuatan mengikat seperti layaknya suatu perjanjian, sehingga seluruh ketentuan pasal-pasal tentang hukum perjanjian telah bisa diterapkan kepadanya.

\section{Penutup}

Berdasarkan pembahasan di atas, maka penulis dapat memberikan kesimpulan bahwa Memorandum of Understanding (MoU) adalah nota kesepahaman dan menjabarkan suatu perjanjian pada bagian pokok-pokoknya saja. Dalam hal ini, mengenai kekuatan hukum yang terdapat di dalam Memorandum of Understanding (MoU) Negara Indonesia tidak mengatur secara tegas. Hal tersebut memperlihatkan 
adanya kekosongan hukum dalam pembuatan perjanjian dan tidak adanya dasar hukum yang kuat. Tetapi ada peraturan terkait Memorandum of Understanding (MoU) yakni Buku III Kitab Undang-Undang Hukum Perdata yang tercantum dalam Pasal 1338 sebagai dasar sanksi bahwa apabila salah satu pihak telah melanggar hal-hal pokok yang tertera dalam isi MoU tersebut. Memorandum of Understanding (MoU) tidak dapat disetarakan dengan kontrak, tetapi suatu MoU merupakan bentuk awal suatu perjanjian yang akan merujuk terhadap suatu kontrak dan memiliki sanksi moral.

Berdasarkan pembahasan yang telah dijelaskan di atas, maka penulis dapat memberikan saran berkaitan dengan Hukum Perjanjian berdasarkan Pasal 1313 KUHPerdata, yaitu suatu perbuatan dengan mana satu orang atau lebih mengikatkan dirinya terhadap satu orang lain atau lebih dan Memorandum of Understanding (MoU) sebagai dasar penyusunan kontrak pada masa datang yang didasarkan pada hasil permufakatan para pihak, baik secara tertulis maupun lisan. Pemerintah harus membuat peraturan perundang-undangan secara jelas tentang Memorandum of Understanding(MoU), karena apabila para pihak ingin membuat suatu pra perjanjian sebelum masuk dalam sebuah kontrak, maka dengan adanya kekuatan hukum di dalamnya sebagai ketentuan yang bersifat memaksa menjadi penting, untuk meminimalisirkan perbuatan kelalaian yang dilakukan oleh para pihak dalam membuat suatu nota kesepahaman tersebut.

\section{Daftar Pustaka}

\section{Buku:}

Budiono Kusumohamidjojo, Perbandingan Hukum Kontrak, Mandar Maju, Bandung, 2015

Djaja S. Meliala, Perkembangan Hukum Perdata Tentang Benda Dan Hukum Perikatan, Nuansa Aulia, Bandung, 2007

H. Salim HS, H. Abdullah, Wiwiek Wahyuningsih, Perancangan Kontrak \& Memorandum of Understanding (MoU), Sinar Grafika, Jakarta, 2014

J. Satrio, Hukum Perjanjian, PT. Citra Aditya Bakti, Bandung, 1992 
R. Wirjono Prodjodikoro, Azas-Azas Hukum Perjanjian, CV. Mandar Maju, Bandung, 2000

R. Subekti, R. Tjitrosudibio, Kitab Undang-Undang Hukum Perdata, PT. Pradnya Paramita, Jakarta, 2005

Soedjono Dirdjosisworo, Kontrak Bisnis, CV. Mandar Maju, Bandung, 2003

Web Document:

Pemikiran dan Referensi Hukum, http://arididit.blogspot.com/2014/10/ terakhir diakses 7 Desember 2015 
